\title{
Sistem Aplikasi Absensi Menggunakan Teknologi Barcode Scanner Berbasis Android
}

\author{
Fitri Ayu ${ }^{1}$ and Ari Mustofa ${ }^{2}$ \\ Program Studi Manajemen Informatika, AMIK Mahaputra Riau ${ }^{1,2}$ \\ fitriayu@amikmahaputra.ac.id ${ }^{1}$, arytafa@gmail.com ${ }^{2}$
}

\begin{tabular}{l}
\hline \hline Article Info \\
\hline History : \\
Dikirim 14 Agustus 2019 \\
Direvisi 04 Oktober 2019 \\
Diterima 21 Desember 2019
\end{tabular}

\section{Kata Kunci:}

Absensi

Android

Aplikasi

Barcode

Scanner

\begin{abstract}
Abstrak
Absensi merupakan salah satu instrument yang sangat penting dalam penyelenggaraan perkuliahan. Oleh karena itu, dibutuhkan pengawasan yang baik mengenai absensi kehadiran mahasiswa, seperti halnya pada Kampus Amik Mahaputra Riau penyelenggaraan pendidikan menerapkan sistem absensi manual menggunakan metode tanda tangan pada lembaran absen yang dibagikan pada setiap perkuliahan. Kelemahannya, sering terjadi kecurangan titip absen, lupa mengisi absen sehingga terjadi kesalahan, serta tidak efisien karena butuh waktu lama dalam perekapan data. Aplikasi Absensi dengan Barcode merupakan solusi yang memanfaatkan Teknologi Informasi Mobile yang mampu menangani permasalahan diatas, karena memiliki keunggulan dapat melakukan pengambilan absensi dengan cepat, tepat dan akurat, sehingga proses rekapitulasi dan monitoring pelaksanaan dan pengelolaan absensi dapat dilakukan secara praktis dan efisien.
\end{abstract}

(C) This work is licensed under a Creative Commons Attribution-ShareAlike 4.0 International License.

\section{Koresponden:}

Fitri Ayu

Program Studi Manajemen Informatika

AMIK Mahaputra Riau

Jln. HR. Soebrantas No. 77 Panam, Pekanbaru, Indonesia, 28294

Email : fitriayu@amikmahaputra.ac.id

\section{PENDAHULUAN}

Perguruan Tinggi merupakan Institusi tertinggi tempat mencetak generasi muda sebagai penentu kemajuan suatu bangsa, untuk itu sudah seharusnya segala aktivitas maupun proses perkuliahan di sebuah perguruan tinggi harus tersentuh oleh perkembangan atau kemajuan teknologi. Seperti halnya pada proses perkuliahan, absensi merupakan faktor penting yang harus diperhatikan, karena perkuliahan dapat berlangsung dengan baik jika adanya keaktifan dan kedisiplinan seluruh mahasiswa dan dosen dalam penyelenggaraan perkuliahan. Namun kenyataanya saat ini proses absensi perkuliahan menggunakan metode tanda tangan pada lembaran absen masih banyak digunakan, seperti pada Perguruan Tinggi AMIK Mahaputra Riau.

Metode ini memiliki banyak kelemahan, sehingga kurang efisien dalam penerapannya, Maka dari itu, peneliti merancang sebuah aplikasi absensi digital berbasis android guna menggantikan sistem absensi manual. Penelitian sebelumnya yang pernah dilakukan yaitu dengan penggunaan alat absensi sidik jari dirasa masih kurang efektif dalam pengambilan data absensi mahasiswa karena hanya dapat digunakan untuk merekam data mahasiswa yang hadir saja. Dari sisi harga, satu unit alat absensi sidik jari sekitar 2 hingga 3 juta rupiah. 
Penggunaan alat absensi sidik jari juga memerlukan pendataan sidik jari seluruh mahasiswa, sehingga kurang praktis dalam penerapan [10]. Aplikasi Absen dengan Barcode Scanner berbasis android merupakan solusi yang memanfaatkan Teknologi Informasi Mobile yang mampu menangani permasalahan selama proses absensi dan dapat mengakomodir proses perekaman data absensi sehingga proses rekapitulasi dapat dilakukan lebih cepat dan akurat [1].

Proses absensi dapat dilakukan dengan menscan kode Barcode yang telah dipersiapkan menggunakan aplikasi yang telah diinstal pada Smartphone selanjutnya mahasiswa akan mengirim data absensi ke kebagian BAAK. Pengambilan Absensi bagi mahasiswa yang tidak hadir pada waktu perkuliahan dapat dilakukan oleh dosen. Dengan diterapkannya absensi menggunakan Barcode Scanner berbasis android dapat mencegah terjadinya kecurangan absensi yang dilakukan sebelum atau sesudah jadwal perkuliahan [2]. Berdasarkan uraian permasalahan diatas, Perancangan Sistem Aplikasi Berbasis Android dengan teknologi barcode scanner menjadi solusi dalam pemecahan masalah pengelolaan data absensi dan memiliki keunggulan dapat melakukan pengambilan absensi dengan cepat, tepat dan akurat, sehingga monitoring pelaksanaan dan pengelolaan absensi dapat dilakukan secara praktis dan efisien.

\section{METODE PENELITIAN}

Teknologi QR barcode dapat diterapkan sebagai media penyimpanan data. Pada penelitian sebelumnya, dengan judul "Sistem Absensi Mahasiswa Menggunakan Metode Barcode Berbasis Android" yang dilakukan oleh I Made Dharma Susila pada tahun 2013 telah dibuktikan bahwa QR code dapat menyimpan data mahasiswa berupa NIM, nama, progam studi, kelas dan matakuliah. Pada penelitian tersebut, QR code disimpan pada setiap ponsel mahasiswa kemudian proses absensi dilakukan dengan menunjukkan gambar yang telah disimpan pada ponsel ke mesin pembaca barcode yang tersedia pada pintu masuk setiap kelas. (I.M. Dharma Susila, 2013) [3].

Penelitian lain yang pernah dilakukan yaitu tentang "Analisa dan Perancangan Aplikasi Wisata dengan Menggunakan Teknologi QR code pada Platform Android” (Studi kasus : Kebun Binatang Ragunan) yang dilakukan oleh Wahyu, Dody Jayadi dan Rusgiarto (2011). Dengan penggunaan aplikasi ini pengguna dapat lebih mudah dan praktis dalam melakukan pencarian informasi objek wisata. Berdasarkan hasil penelitian ini dapat disimpulkan bahwa Aplikasi yang dibuat dapat melakukan scan QR code untuk memperoleh informasi serta peta digital lokasi objek wisata sehingga dapat membantu para pengunjung yang hendak menikmati objek wisata kebun binatang ragunan [4].

Dari permasalahan dan penelitian yang pernah dilakukan diatas, penulis merancang suatu sistem aplikasi absensi menggunakan teknologi mobile berbasis android yang hendak diterapkan pada Perguruan Tinggi AMIK MAHAPUTRA RIAU, sehingga proses pelaksanaan dan perekapan data absensi juga dapat dilakukan dengan lebih efesian dan praktis.

Selanjutnya, untuk urutan kegiatan yang dilakukan menuju penyelesaian sistem. Pekerjaan pengembangan sistem mengikuti metode pengembangan sistem klasik, sebagai berikut:

\section{Kebutuhan Sistem}

Sistem yang dibangun ini bertujuan untuk mengatasi masalah merekam kehadiran siswa di kelas melalui penggunaan aplikasi absensi berbasis Android. Dengan harapan user yang akan menggunakan aplikasi sudah memiliki Perangkat Android, aplikasi yang dibangun dapat mengatasi masalah absensi dan dapat merekam data absensi dengan tepat dan cepat. Berbeda dengan sistem manual yang masih dilakukan dengan paraf dilembar absensi, aplikasi absensi yang dibuat sangat membutuhkan pengaturan minimal. Selain itu, perangkat Android biasanya kecil, ringan dan portabel, yang memungkinkan user untuk digunakan dengan mudah di mana saja dan kapan saja.

\section{Desain Sistem}

Sistem Aplikasi absensi menggunakan barcode scanner berbasis android dirancang sebagai aplikasi berbasis client server yang mana database berada pada komputer server sementara aplikasi absensi diinstal pada masing-masing perangkat mobile dari pengguna dan bertindak sebagai client yang berfungsi untuk menginput data absensi menggunakan barcode dengan cara user menscan barcode absensi yang 
berisikan data kode absen, selanjutnya data absensi disimpan kedalam database yang ada dikomputer server [5].

Untuk mengelola data absensi diperlukan sebuah aplikasi berbasis desktop yang digunakan sebagai pusat untuk mengatur data pendukung yang akan digunakan untuk proses absensi, seperti terlihat pada gambar 1.

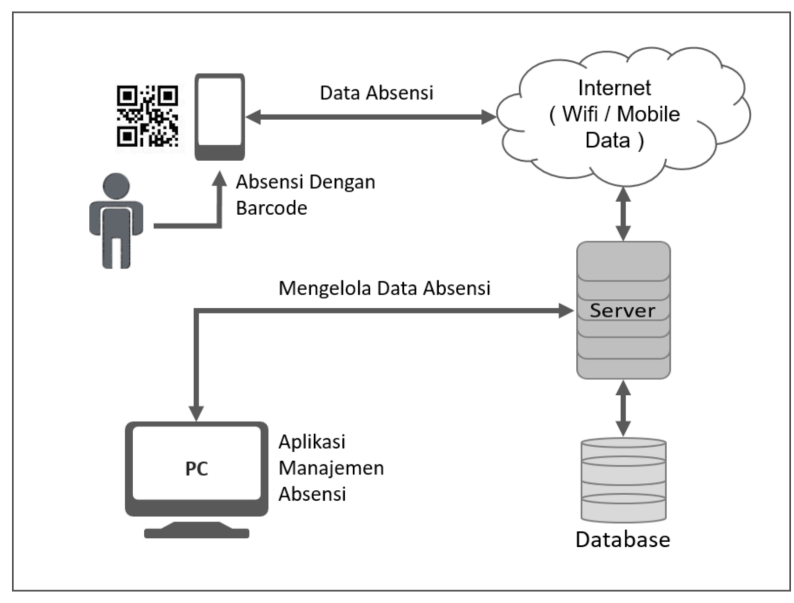

Gambar 1. Desain Sistem

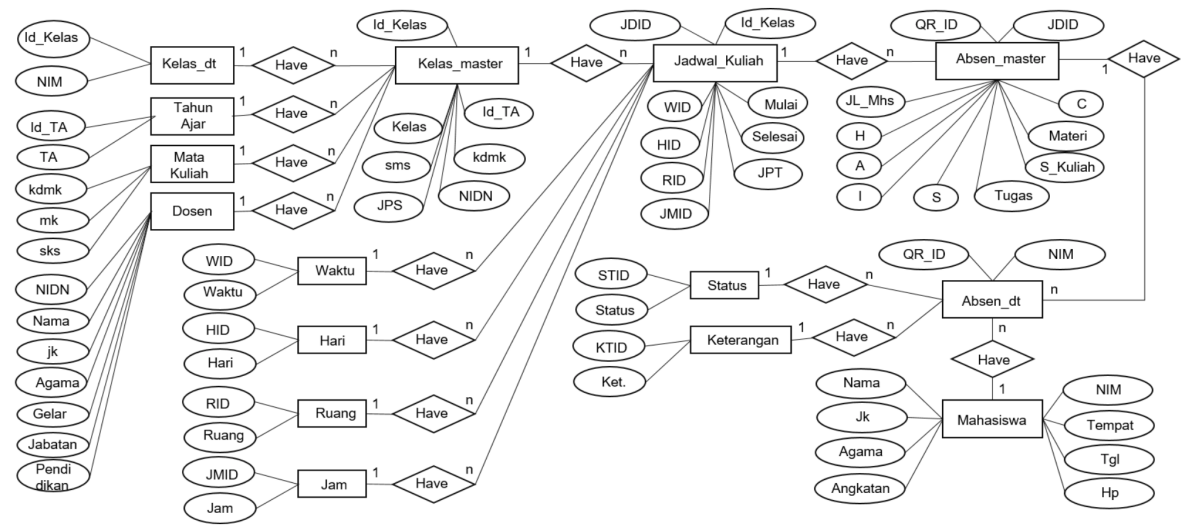

Gambar 2. ERD

\section{ERD (Entity Relationship Diagram)}

Suatu model untuk menjelaskan mengenai hubungan antar data dalam basis data berdasarkan objek-objek dasar data yang memiliki hubungan antar relasi. Entity Relationship Diagram digunakan untuk memodelkan struktur data serta hubungan antar data, untuk dapat menggambarkannya digunakan beberapa notasi serta symbol [6].

Database berperan sangat penting dalam sistem absensi karena sangat dibutuhkan untuk menyimpan informasi yang dibutuhkan dalam proses absensi. Dalam database terdiri dari sejumlah tabel yang digunakan untuk menyimpan berbagai kelompok data yang diperlukan untuk mengelola data absensi mahasiswa, pada dasarnya ada beberapa tabel khusus seperti absensi, kelas, jadwal, dosen, mahasiswa dan matakuliah. Tabel absensi menyimpan rincian informasi absensi, tabel kelas menyimpan data kelas perkuliahan, tabel jadwal menyimpan informasi jadwal perkuliahan, tabel dosen menyimpan informasi dosen, tabel mahasiswa menyimpan informasi mahasiswa, dan tabel matakuliah menyimpan informasi matakuliah, seperti terlihat pada gambar 2. 


\section{Implementasi Sistem}

Sistem absensi diimplementasikan untuk proses absensi, diawali dengan user menginstal aplikasi absensi berbasis android melalui file apk, selanjutnya user melakukan login untuk masuk kemenu absensi. Setelah login berhasil aplikasi akan menampilkan menu absensi. Untuk proses absensi dilakukan dengan cara menscan barcode jadwal perkuliahan yang sebelumnya telah dibuat oleh admin. Selama proses scan aplikasi membuka scanner barcode dengan mengaktifkan camera handphone selanjutnya akan langsung menscan barcode. Selama proses scanning aplikasi melakukan pengecekan terhadap barcode dan mencocok kode barcode dengan nim mahasiswa untuk mengetahui status mahasiswa terhadap kode barcode. Setelah pengecekan berhasil maka aplikasi akan menampilkan detail informasi mengenai kelas perkuliahan berdasarkan kode barcode yang discan. Selanjutnya mahasiswa mengirimkan data absensi kedalam database melalui aplikasi seperti terlihat pada gambar 3 dan gambar 4.

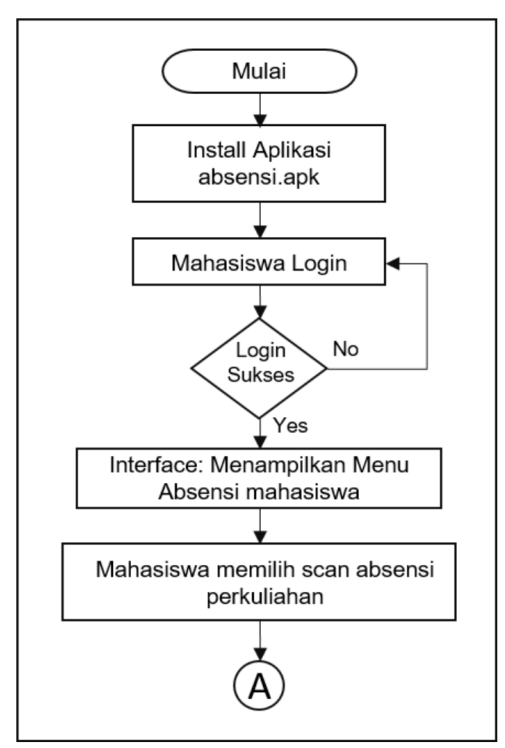

Gambar 3. User Mempersiapkan Aplikasi

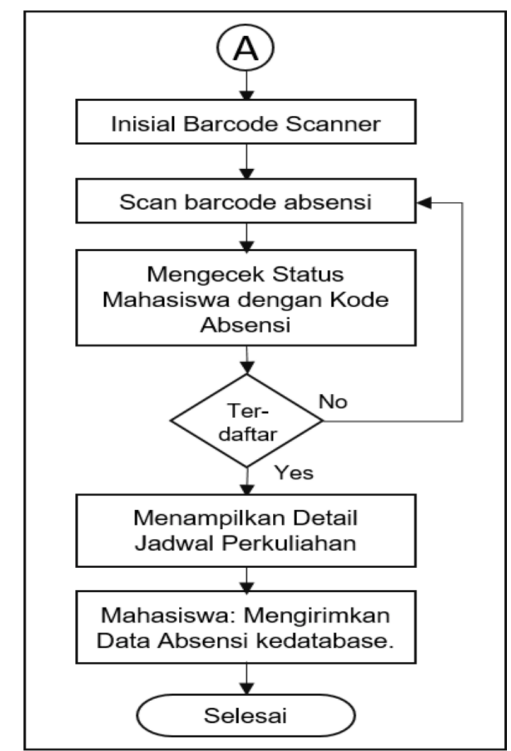

sensi

\subsection{Pengumpulan Data}

Data yang dibutuhkan pada penelitian ini adalah data absensi seluruh mahasiswa dan dosen yang aktif pada Yayasan Perguruan Tinggi AMIK Mahaputra Riau selama tahun ajaran 2018-2019. Dalam pengumpulan data yang dibutuhkan untuk penelitian ini, selain peneliti yang berperan aktif, juga dibantu oleh 2 (dua) orang sebagai pengumpul data.

\subsection{Konsep Teori}

\subsubsection{Absensi}

Absensi adalah suatu pendataan kehadiran, bagian dari pelaporan aktifitas suatu institusi, atau komponen institusi itu sendiri yang berisi data data kehadiran dan ketidak hadiran yang disusun dan diatur sedemikian rupa sehingga mudah untuk dicari dan dipergunakan apabila sewaktu waktu diperlukan oleh pihak yang berkepentingan [7].

Kehadiran merupakan suatu keharusan bagi mahasiswa, tanpa kehadiran dosen tidak dapat menilai partisipasi mahasiswanya. Pengelolaan data kehadiran yang masih dilakukan secara manual pada lembaran kertas menimbulkan beberapa masalah, seperti : penggunaan kertas dalam jumlah yang banyak, kesulitan bagi administrasi dalam melakukan perekapan dan kecurangan absensi yang sering dilakukan mahasiswa. Makanya 
saat ini banyak dikembangkan sistem absensi digital yang dapat melakukan perekapan data secara cepat, tepat dan efisien [8].

\subsubsection{Barcode}

Quick Response Code (QR) merupakan model bercode (2D) jenis baru yang berbentuk pola dari hasil gabungan garis horizontal dan vertikal yang lebih flexsibel dan lebih cepat dari jenis label barcode batang (1D), sehingga dalam proses scan code barcode yang tersimpan dalam pola QR Code pada Aplikasi yang dirancang dapat dibaca dengan cepat [9].

Dalam proses penggunaanya juga lebih mudah karena dapat dibaca oleh siapa saja dengan smartphone dan aplikasi pembaca barcode sederhana lainnya yang berbasis android sehingga seluruh mahasiswa dapat menggunakan aplikasi ini. QR Code juga dapat menyimpan informasi lebih banyak dengan pola ukuran yang tetap kecil sehingga seluruh informasi mengenai pengolahan data absensi dapat disimpan kedalam satu pola atau gambar QR Code. Dari semua kelebihan yang dimiliki QR Code itu lah peneliti memilih pembuatan aplikasi absensi menggunakan barcode scanner tipe QR Code [4].

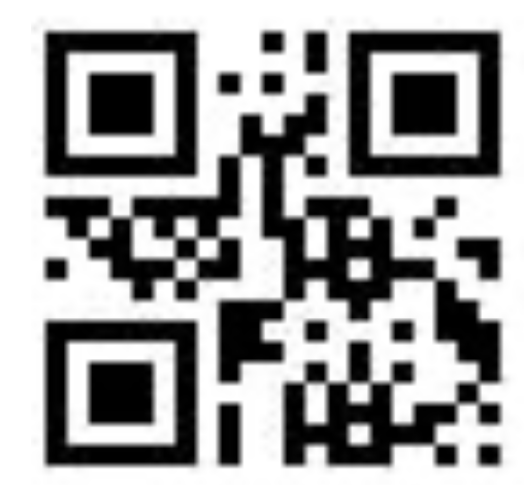

Gambar 5. Barcode

\subsubsection{Android}

Android Merupakan salah satu sistem operasi mobile open source yang memungkinkan pengguna dapat mengembangkan aplikasi yang akan dijalankan diatas sistem operasi android [10]. Sehingga banyak para pengguna lebih menggunakan sistem operasi adroid dalam mengembangkan aplikasi dan dapat digunakan secara mudah dan portable. Aplikasi yang dibangun dalam penelitian ini merupakan aplikasi yang dikembangkan untuk dijalankan di android dengan menggunakan barcode sebagai pendukung dalam penggunaannya [11].

\section{HASIL DAN PEMBAHASAN}

Hasil dari penelitian ini adalah berupa sistem aplikasi absensi dengan menggunakan barcode scanner berbasis Android. Dimana aplikasi ini dibagi menjadi dua jenis aplikasi, aplikasi pertama adalah aplikasi berbasis desktop yang digunakan oleh admin untuk mengelola seluruh data yang diperlukan dalam proses absensi. Sementara aplikasi berikutnya adalah Aplikasi berbasis android yang digunakan oleh Dosen dan mahasiswa untuk keperluan proses absensi.

\subsection{Halaman Aplikasi Desktop}

Aplikasi berbasis desktop merupakan aplikasi yang dijalankan Oleh Admin dan dibangun untuk mengelola seluruh data yang diperlukan dalam proses absensi [12]. Pada aplikasi ini terdapat menu antara lain: Data master dengan sub-menu: Mahasiswa, Dosen, Matakuliah, Menu Akademik dengan sub-menu: Registrasi, Kelas Perkuliahan, Jadwal Perkuliahan, Barcode Generator, Absensi, Menu Laporan dengan sub-menu: 
Laporan Registrasi, Laporan Jadwal, Laporan Kelas, Laporan Absensi. Untuk hierarki sistem aplikasi pengelolaan absensi, seperti terlihat pada gambar 6 berikut.

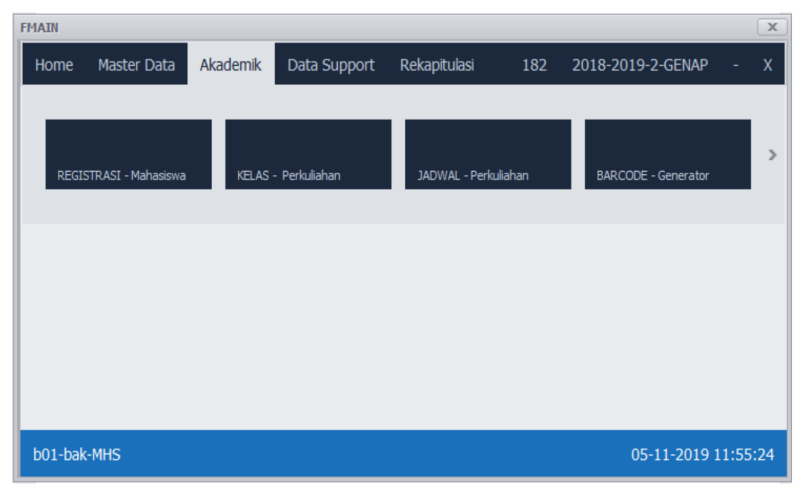

Gambar 6. Tampilan Menu Aplikasi pengelolaan absensi

(a) Login

Tampilan Login Merupakan halaman pintu masuk admin untuk mengoperasikan aplikasi ini lebih jauh. Halaman ini di peruntukkan khusus untuk admin yang langsung mengelola Data-data yang diperlukan dalam proses absensi. Proses login dilakukan dengan menginputkan usename dan password, kemudian sistem akan memverifikasi username dan password. Apabila login berhasil akan masuk ke halam dashboard, sebaliknya bila login gagal maka menampilkan pesan kesalahan.

(b) Manajemen Registrasi Mahasiswa

Halaman ini digunakan untuk mengelola data registrasi mahasiswa pada setiap semester. Data registrasi digunakan untuk membuat daftar kelas perkuliahan.

(c) Manajemen Kelas Perkuliahan

Halaman ini digunakan untuk mengelola data Kelas Perkuliahan pada setiap semester. Data Kelas perkuliahan merupakan data peserta yang mengambil matakuliah dalam satu semester dan digunakan untuk membuat Jadwal perkuliahan.

(d) Manajemen Jadwal Perkuliahan

Halaman ini digunakan untuk mengelola data Jadwal Perkuliahan pada setiap semester. Data Jadwal perkuliahan merupakan data Jadwal Perkuliahan yang akan dilaksanakan dalam satu semester.

(e) Manajemen Barcode Absensi

Halaman ini digunakan untuk mengelola data Barcode absensi dengan data referensi diambil dari data Jadwal Perkuliahan pada setiap semester. Data Jadwal perkuliahan merupakan data Jadwal Perkuliahan yang akan dilaksanakan dalam satu semester.

(f) Manajemen Absensi

Halaman ini digunakan untuk mengelola data absensi yang dihasilkan dari proses pengambilan data absensi menggunakan barcode yang dilakukan oleh Dosen dan mahasiswa.

\subsection{Halaman Aplikasi Android}

Proses utama untuk memulai penggunaan Aplikasi Absensi Menggunakan Teknologi Barcode Scanner Berbasis Android ini yaitu dengan mengklik menu Login, yang membutuhkan username dan password pengguna, seperti terlihat pada gambar 8.

Setelah berhasil Login akan masuk ke Menu Mahasiswa maka akan muncul data mahasiswa dan menu pilihan: Absen kelas dan Rekap Absen, seperti terlihat pada gambar 9. 


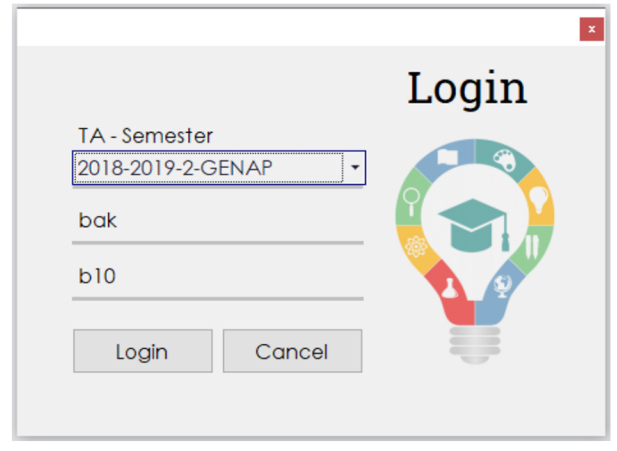

(a)

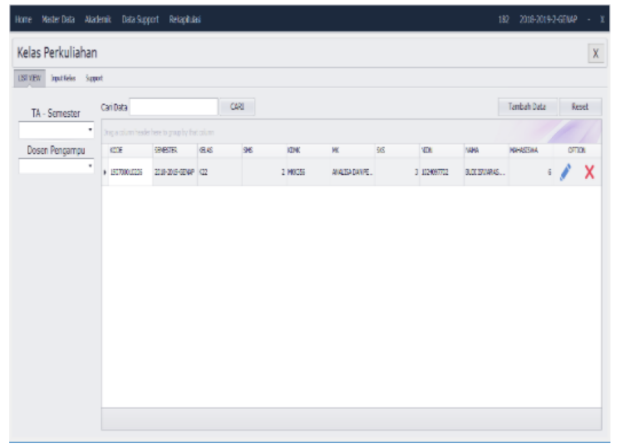

(c)

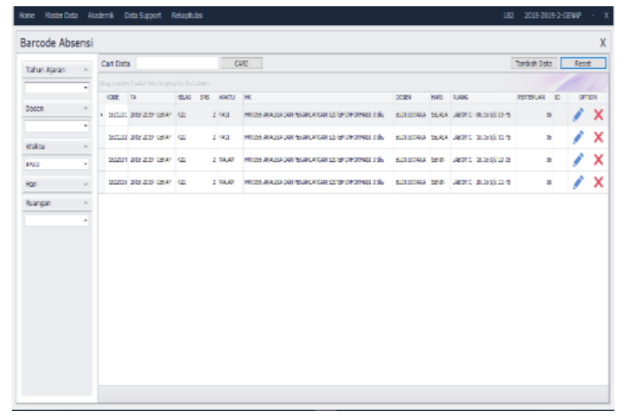

(e)

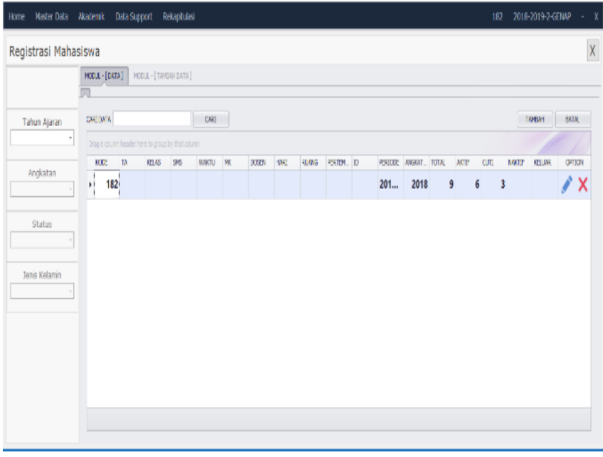

(b)

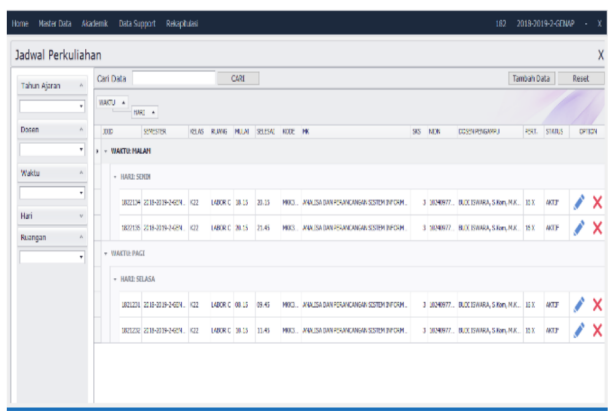

(d)

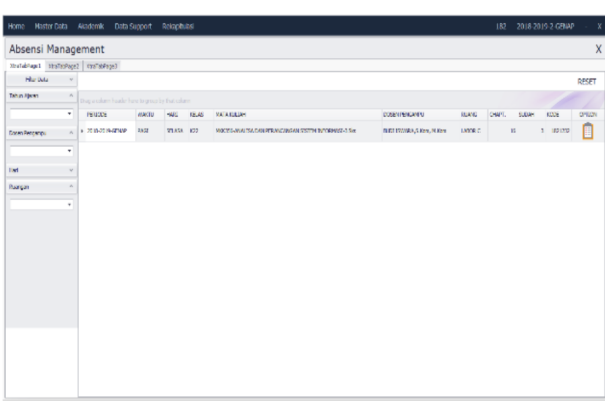

(f)

Gambar 7. Form modul pengelolahan data absensi (a) Login, tampilan awal aplikasi sebelum masuk ke menu utama; (b) Modul Manajemen Registrasi Mahasiswa; (c) Modul Manajemen Kelas Perkuliahan;(d) Modul Manajemen Jadwal Perkuliahan; (e) Modul Manajemen Barcode Absensi; (f) Modul Manajemen Absensi.

Kemudian proses absensi dapat dilakukan melalui menu absen mahasiswa dengan memilih menu absen kelas, proses absensi diawali dengan menscan kode Barcode selanjutnya akan menampilkan deskripsi kelas perkuliahan seperti : jadwal, matakuliah, dosen pengampu. Selanjutnya untuk mengirim data absen ke dalam database dilakukan dengan cara menekan opsi Submit Absen, seperti terlihat pada gambar 10.

\section{KESIMPULAN}

Penelitian ini telah berhasil dilakukan dan memberikan beberapa kesimpulan yaitu :

1. Dalam pengujian Absensi dengan menggunakan kode barcode melalui aplikasi android dapat mengatasi Kelemahan dalam penerapan absensi dengan metode manual melalui form absensi dengan lembaran kertas sehingga data absensi dapat direkam dengan baik dan benar. 


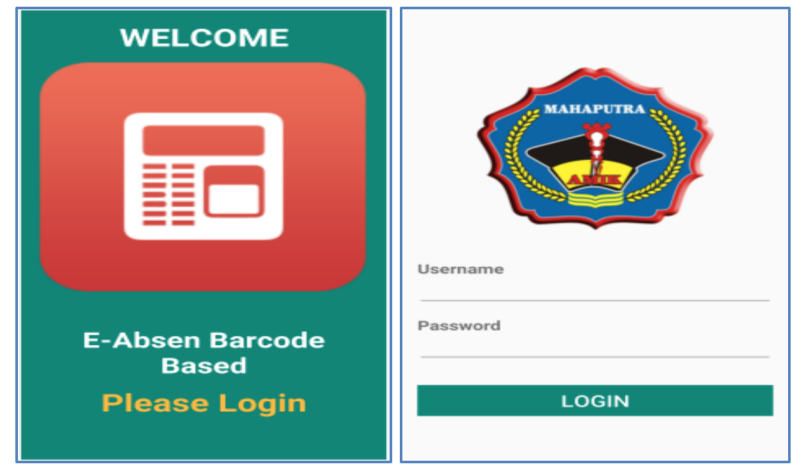

Gambar 8. Menu Login

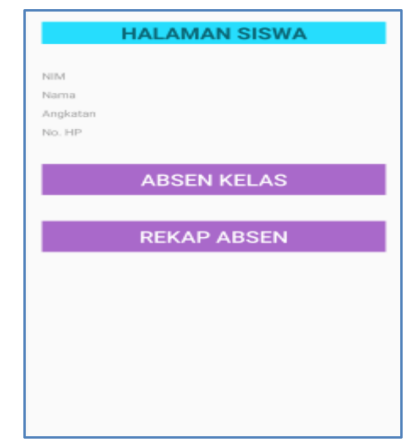

Gambar 9. Main Menu

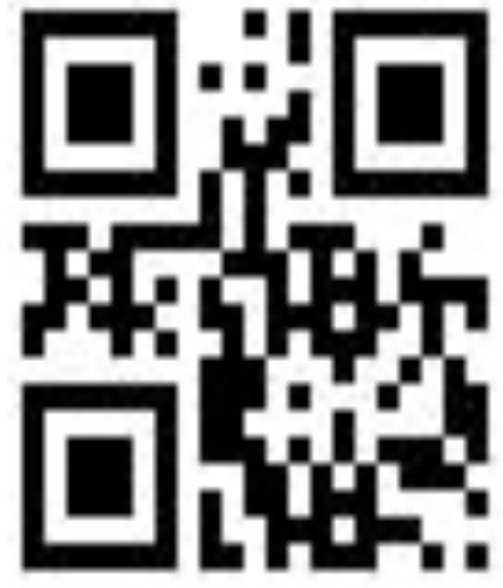

Gambar 10. Barcode Absensi

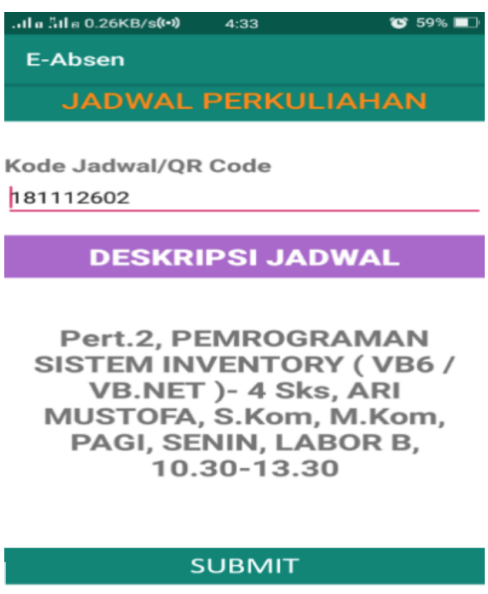

Gambar 11. Hasil Scan Barcode

2. Data absensi yang telah diinput mencatat data berupa data jadwal, user atau mahasiswa yang melakukan absen dan waktu saat melakukan proses absensi dapat diketahui secara cepat oleh petugas BAAK dan user yang terkait dalam proses absensi.

3. Dalam proses rekapitulasi Absensi dapat dilakukan dengan lebih mudah, cepat dan akurat karena data absensi tersimpan dalam satu file database yang dapat langsung diakses oleh BAAK, sehingga tidak diperlukan lagi perhitungan manual dalam proses rekapitulasi absensi.

4. Aplikasi belum bisa merekam posisi point (maps point) dari user yang melakukan absensi, belum ter- 
hubung dalam hal keuangan yang menyangkut masalah rekapitulasi absensi yang dapat dilihat oleh dosen.

\section{UCAPAN TERIMA KASIH}

Penulis mengucapkan terima kasih yang sebesarnya kepada Kementerian Riset dan Teknologi Pendidikan Tinggi (KEMENRISTEK DIKTI) yang telah memberikan dukungan Finansial terhadap penelitian ini sehingga penelitian ini dapat terlaksana dengan baik.

\section{DAFTAR PUSTAKA}

[1] S. A. M. Noor, N. Zaini, M. F. A. Latip, and N. Hamzah, "Android-based attendance management system," in 2015 IEEE Conference on Systems, Process and Control (ICSPC). IEEE, 2015, pp. 118-122.

[2] M. A. Hidayat and H. M. Simalango, "Students attendance system and notification of college subject schedule based on classroom using ibeacon," in 2018 3rd International Conference on Information Technology, Information System and Electrical Engineering (ICITISEE). IEEE, 2018, pp. 253-258.

[3] I. MADE and D. SUSILA, "Sistem absensi mahasiswa menggunakan metode barcode berbasis android," Ph.D. dissertation, UPN" veteran” Jawa Timur, 2013.

[4] F. Ayu and A. Mustofa, "Sistem aplikasi absensi menggunakan teknologi barcode scanner berbasis android," IT JOURNAL RESEARCH AND DEVELOPMENT, vol. 4, no. 2, 2019.

[5] A. Sangiovanni-Vincentelli and G. Martin, "Platform-based design and software design methodology for embedded systems," IEEE Design \& Test of Computers, vol. 18, no. 6, pp. 23-33, 2001.

[6] I.-Y. Song and K. Froehlich, "Entity-relationship modeling," IEEE Potentials, vol. 13, no. 5, pp. 29-34, 1994.

[7] Y. Zhang, G. Su, and W. Zheng, "Converting legacy desktop applications into on-demand personalized software," IEEE Transactions on Services Computing, vol. 3, no. 4, pp. 306-321, 2010.

[8] S. Kadry and M. Smaili, "Wireless attendance management system based on iris recognition," Scientific Research and essays, vol. 5, no. 12, pp. 1428-1435, 2010.

[9] S. Tiwari, "An introduction to qr code technology," in 2016 International Conference on Information Technology (ICIT). IEEE, 2016, pp. 39-44.

[10] B. Bergvall-Kåreborn, M. Björn, and D. Chincholle, "Motivational profiles of toolkit users-iphone and android developers," International Journal of Technology Marketing, vol. 6, no. 1, pp. 36-56, 2011.

[11] S. Brahler, "Analysis of the android architecture," Karlsruhe institute for technology, vol. 7, no. 8, 2010.

[12] S. B. Utomo and B. Hendradjaya, "Multifactor authentication on mobile secure attendance system," in 2018 International Conference on ICT for Smart Society (ICISS). IEEE, 2018, pp. 1-5.

\section{BIOGRAFI PENULIS}

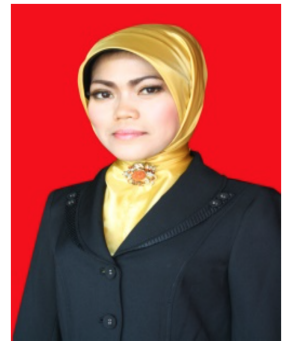

Fitri Ayu Received the Bachelor of Computer Science in 2009 and Master of Information Technology in 2011 from Universitas Putra Indonesia "YPTK" (UPI "YPTK" Padang) Currently, she has been Lecturer in College of AMIK Mhaputra Riau, the Faculty of Information Engineering of Riau University, and also an Assistant in An-Namiroh Education Foundation, Pekanbaru since 2012. Her current research interest are Programming and Android Applications making. 


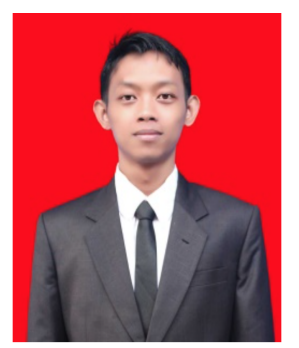

Ari Mustofa Received the Bachelor of Engineering from Institut Teknologi Medan in 2009 and Master of Information Technology in 2018 from Universitas Putra Indonesia "YPTK" (UPI "YPTK" Padang) Currently, she has been a Lecturer in College of AMIK Mahaputra Riau, Research that is of interest right now is programming and making desktop and Android based applications. 